\title{
Power in International Human Rights
}

\section{Gage Martinez}

There are immediate difficulties presented by human rights internationally, such as how to conceptualize and enforce them. Upon both a conceptual analysis of human rights and a review of their usage in practical application, the noble picture painted by human rights is unfortunately sullied. By using a three-dimensional view of power, I argue that the very concept of human rights is warped by power relations and ultimately reflective of the imbalances between nations. Furthermore, I reveal a distinction between the influence of political interests and of business interests in the application of human rights. Ultimately, even human rights, a concept that is designed to be equal, all too often becomes a tool to produce inequalities and domination.

Keywords: human rights, power, international law, rights, ethics, philosophy

Following World War II, the Universal Declaration of Human Rights of 1948 codified human rights across the globe. The legacy of human rights in international law, however, raises many doubts as to the true universality of its application. At the end of the day, even what are supposed to be the most equal, fundamental rights are affected by power relations. There are obvious biases on the surface of international human rights, namely selective enforcement, which is a problem itself, but it can also be analyzed to show a deeper underlying problem. Steven Lukes' "three-dimensional power" is indispensable in revealing this. Under a three-dimensional conception of power, one must not only look at which groups are accused of human rights violations and which groups are not, but also look at the power structures that determine which human rights are protected in the first place.

Let's begin with an overview of Lukes' three-dimensional power. Power is sectioned into three different tiers with increasingly subtle influence. The first dimension is the obvious sense of power; there is a clear situation in which A can force B to do something through observable decisions (Lukes 17). Second dimensional power expands to take into account non-decision making as well; what is both done and not done (in other words, what is intentionally ignored) can be demonstrations of power (Lukes 22). This second dimension of power in particular describes the manipulation of what issues are considered, by giving them attention and credence or not. However, both decisions and non-decisions are taken to be conscious choices and both first and second dimensional power only looks at observable conflict. The third dimension of power is the manipulation of preference so as to never allow certain issues to be considered in the first place (or only allow them to be considered in particular ways). This can be exercised through societal norms, economic relations, or historical circumstances rather than the 
decisions of individual agents (Lukes 28). There are more aspects of each dimension, but these are the relevant senses for this discussion.

Historically, human rights only arose in the form we understand around the mid-20th century. In a very reductive way, they could be summarized as natural rights' application to international law. This means that human rights are the fundamental rights afforded to all people and are inalienable. To get a sense for it, here are some rights that were listed in the Universal Declaration of Human Rights in 1948: the right to life, liberty, security, freedom of movement, work, governmental representation, free education, and health. To this day, there is much debate over which rights are human rights as well as the breadth to which they extend.

Human rights have served primarily to give a foundation for international law. Subsequently there is a large body of law dealing directly with human rights and how they are upheld by various international institutions through declarations and conventions. The difference between these two concepts lies in the degree to which they are binding. Declarations, like the Universal Declaration of Human Rights, have no enforcement power but are frequently used as a guide by all nations to make claims about human rights. The degree to which declarations are respected by a nation varies, mostly in accordance with how well the nation can get away with violating them. Conventions are the legally binding documents that are much more tightly written and focus on specific rights, such as freedom from torture or slavery. Most are under the purview of the UN, and in the rare case they actually go into effect, the International Court of Justice has jurisdiction. The question of jurisdiction is an important one, particularly regarding universal jurisdiction. Universal jurisdiction claims that any court can prosecute violations of international law; for example Nigeria's court could prosecute Israeli leaders for human rights violations if there was universal jurisdiction. We will return to universal jurisdiction when analyzing power.

It should not come as a great surprise that there are biases in the application of international law, particularly when it comes to human rights. If one looks, it is easy to find clear discrepancies in who gets punished for human rights violations and who does not. These will be demonstrations of the second dimension of power in play. The primary Non-Governmental Organization (NGO) in matters of international human rights is the Human Rights Watch (HRW). HRW acts as a sort of beacon that illuminates human rights violations. It has no power of enforcement itself, but nations around the world look to HRW for information regarding the abuses of human rights that occur around the globe. The funding of HRW should hint at what gets highlighted and what does not. In 2009, out of the $\$ 44$ million in public donations they received, nearly $75 \%$ of their donations came from North America, nearly $25 \%$ from Western Europe, with the remaining $1 \%$ being from the rest of the world. Perhaps as a result of this, the HRW has been accused of "[furthering] capitalist values and [discrediting] governments seeking socialist alternatives" (Leech). A shining example is their claim that Venezuela under Hugo Chavez was "the most abusive nation" in Latin America, releasing an extensive report greatly overstating the human rights abuses. Colombia, on the other hand, has such a gross record that there is no conceivable competition between them and Venezuela under Chavez. There is little doubt that this helped lead to the sanctions that have ravaged Venezuela since then.

Perhaps the worse issue is when human rights violations are recognized but conveniently ignored. There is a saddeningly large pool of examples to pull from. Saudi Arabia has a notably poor history of human rights overall, but there is a fine example from recent memory. I am referring to the assassination of the journalist and outspoken critic of the Saudi royal family, Jamal Khashoggi, by the Saudi government. The response of the international community was that of nearly universal condemnation, and yet there were no attempts to put any international law into effect. One would expect that openly assassinating dissidents would motivate embargoes, sanctions, or at least some form of indirect punishment. The actual result is to the contrary. The Trump administration began sharing sensitive nuclear data with Saudi Arabia just sixteen days after the assassination; furthermore, President Trump vetoed three bills aimed at suspending an $\$ 8.1$ billion arms deal with them. Canada's government stated that it would suspend its pending $\$ 13$ billion deal, but has since proceeded with it. 
Human rights abuses are willingly ignored when it is in the interest of powerful nations to do so, as with the Saudi arms deal and countless others, and are exaggerated when a nation falls out of line with the Western hegemon, as with Venezuela. To be clear, this is not just in the case of the power of western nations. Other nations with power have exercised human rights in this manner as well, as seen in the UN during the Cold War for example. During the 1970s and 80s, Israel, Chile, and apartheid South Africa gained their rightful status as pariah states. In an analysis of time spent in the UN General Assembly from 1955 to 1988 discussing human rights, these three states virtually dominated discussion. Almost entirely absent from the discussion were the Soviet allied nations, such as Poland and Afghanistan. Similarly absent was any discussion of the atrocities being committed in East Timor by Indonesia, which was backed by western power, as well as other western allied regimes. The force with more power and influence at the UN at the time, be it US or Soviet allies, determined the human rights abuses which were brought into focus. And indeed the US and USSR in particular were "among the most biased of all countries in the United Nations when it [came] to human rights" (Donnelly 299). And accordingly, those nations which had little power but great prestige, such as the Netherlands, showed a much more even record in addressing human rights.

When it comes to powerful nations, it is clear that the usage of human rights either in rhetoric or enforcement is more a tool for national interests than any actual commitment to the rights themselves. Reading an address by the former Secretary of State under the Clinton administration, Madeleine Albright, highlights this in a stark manner. She lambasts Saddam Hussein's regime in Iraq for refusing to "sell oil to buy food" (Albright 599). She continues to criticize the regime for investing in "residential and infrastructure projects that benefit a very few." This is all part of a call to enforce international human rights law. And indeed, in her view international law was designed to "one day defeat communism and promote democratic values and respect for human rights around the world." It would appear that Iraq only came under fire from the Clinton administration as a result of being a target of US power, not because of any legitimate reverence for human rights.

Thus far these have all been demonstrations of second dimensional power. Third dimensional power, however, is even more manipulative. The third dimension of power allows those in power to determine what rights are human rights at all. This is a subtle, but massively important ability. There is a hint given in Albright's line about "democratic values." This is significant because it is not just making a claim about which nation violated human rights or not, it makes a fundamental value judgment about rights themselves. Noam Chomsky reveals a way to decode this. "Democracy has an official meaning which is something like [the public running their own affairs]," but the meaning that is commonly used is quite different. "Something is democracy if it is run by the business classes" (Chomsky 66). The idea behind this is that, in rhetoric, the West is synonymous with democracy, and it is democracy that economically strong western nations spread throughout the world. That is an idealistic portrayal of international affairs, to say the least. A more realistic idea is that these nations are, due to their economic systems, dominated by business interests, and therefore those interests extend to international policy. What is being spread is not democracy, but economic power.

There have only been a handful of nations that have enacted universal jurisdiction, and the list says a lot. It is almost solely composed of the economically dominant western nations. One notable exception is Malaysia, who tried the architects of the Iraq war in absentia and convicted many of them. They then referred their decision to the International Court of Justice where it was completely ignored. Malaysia's attempt to hold George W. Bush and Tony Blair accountable for their real war crimes was an almost comically vain effort; that should say something about the power of western nations internationally.

It is clear that the bias in the definition of human rights has its underpinnings in economic power, but how is that manifested? First we must consider the Second Bill of Rights, proposed by President Franklin D. Roosevelt in 1944. It enumerated economic rights, such as the right to employment, to housing, to healthcare, to education and more. Those rights are all but alien to an American now. It is a generalization, but the extent to which economic 
and social rights are recognized as human rights largely depends on the strength of the "democracy." Democracy here means, as Chomsky put it, a government "run by the business class." This is reflected in international policy as well. The US, along with most western nations, are concerned primarily with promoting "civil and political rights," and refuse to recognize the "requirement of governments to guarantee ... social and economic rights" (Leech). As discussed before, there is little concern with civil and political rights either, and when there is, there is bias towards certain elements over others: for example, racial discrimination more than political censorship (Donnelly 285). The mere fact that economic and social rights, despite being more fundamental than civil and political ones, are not often elevated to the level of human rights is a haunting exercise of third dimensional power. If the right to healthcare were taken as seriously as, say, freedom from racial discrimination, it is not hard to imagine what sort of reaction the international community would have to the US medical system. Similarly, if the right to employment was a serious international concern, virtually every nation on the planet, particularly the powerful capitalist nations, would be horrific violators of human rights. In the realm of economic rights the powerful nations would be as guilty as any other nation. In terms of civil and political rights, yes, powerful nations often ignore their own violations yet punish those same violations in other countries. However the less powerful nations have much worse records on those rights. The problem is not that the less powerful nations are being held accountable, but that they are being held accountable unequally. For social and economic rights, no one is being held accountable at all on an international scale. That is third dimensional power.

This three-dimensional approach to power is important when considering international politics. The differences between the second and third dimensions can lead one to very different conclusions. In the second dimension, power is exerted by powerful political entities in matters of civil or political rights. The conflict is direct, though it has its subversions. The interests violated are, accordingly, political or civil ones. The third dimension changes the dynamic. Power is exerted by business interests in matters of social and economic rights. And if social and economic rights are wholesale ignored or denied, there is no justice involving them. Furthermore, these business interests drive most political interests, at least for powerful capitalist nations such as the US. In the third dimension as well, it is the general populace who are having power exerted on them by the dominant business class, instead of one state by another in second dimensional power.

The obvious conclusion to be drawn here is the recognition of the absurd power of business interests, as well as a need for increased awareness of economic rights. Power operates in insidious ways; its strength comes from its secrecy. Once revealed, however, systems and attitudes can change with surprising rapidity. Though that itself is the challenge: if this malignant influence on human rights is shown, toppling it should prove to be a doable task. 


\section{References}

Albright, Madeleine K. "Enforcing International Law." Proceedings of the Annual Meeting (American Society of International Law), vol. 89, 1995, pp. 574-580. JSTOR, www.jstor.org/stable/25658981. Accessed 19 Dec. 2020.

Chomsky, Noam, David Barsamian, and Arthur Naiman. How the World Works. Berkeley, CA: Soft Skull Press, 2011. Print.

Donnelly, Jack. "Human Rights at the United Nations 1955-85: The Question of Bias." International Studies Quarterly, vol. 32, no. 3, 1988, pp. 275-303. JSTOR, www.jstor.org/stable/2600444. Accessed 19 Dec. 2020

"Human Rights Watch Visit to Saudi Arabia." Wayback Machine, web.archive.org/web/20090722190606/www. hrw.org/en/node/84512.

Klein, Betsy and Zachary Cohen. "Trump Vetoes 3 Bills Prohibiting Arms Sales to Saudi Arabia." CNN, 25 July 2019, edition.cnn.com/2019/07/24/politics/saudi-arms-sale-resolutions-trump-veto/index.html.

Leech, Garry. "The Bias of Human Rights Watch." Critical Legal Thinking, 20 Dec. 2014, criticallegalthinking. com/2013/03/21/the-bias-of-human-rights-watch/.

Lukes, Steven. Power: A Radical View. 2nd ed., Palgrave Macmillan, 2009.

Mortada, Dalia. "Canada Set To Go Ahead With Arms Deal, Saudi Arabia Says." NPR, 4 Mar. 2019, www.npr. org/2019/03/04/700055559/canada-set-to-go-aheadwith-arms-deal-saudi-arabia-says.

Ridley, Yvonne. "Bush Convicted of War Crimes in Absentia." Foreign Policy Journal, 6 Mar. 2020, www.foreignpolicyjournal.com/2012/05/12/ bush-convicted-of-war-crimes-in-absentia/.

UN General Assembly. "Universal Declaration of Human Rights." United Nations, 1948, Paris, art. 1, http://www. un.org/en/universal-declaration-human-rights/. 